was funded by North East Thames Regional Health Authority.

1 British Medical Association. A code of practice for the safe use and disposal of sharps. London: BMA, 1990.

2 Advisory Committee on Dangerous Pathogens. HIV-the causative agent of AIDS and related conditions. 2nd ed. London: HMSO, 1990.

3 Department of Health Expert Advisory Group on AIDS. Guidance for clinical health care workers: protection against infection with HIV and hepatitis viruses. London: HMSO, 1990.

4 Centrs for Disease Control. Guidelines for prevention of transmission of human immunodeficiency virus and hepatitis B virus to health care and public safety workers. $M M W R$ 1989;38.S 6

Yassi A, McGill M, Jeanson S, Sekla L. Anti HBs protection in hospital workers vaccinated against hepatitis $B$ : policy implications of a pilot study. Br f Indust Med 1990;47:645-8.

6 Porteous MJ LeF. Operating practices and precautions taken by orthopaedic surgeons to avoid infection with HIV and hepatitis B virus during surgery.

7 Burden AD, Whorwell PJ. Poor uptake of hepatitis B immunisation amongs hospital-based health care staff. Postgrad Med F 1991;67:256-8.

8 Astbury C, Baxter PJ. Infection risks in hospital staff from blood: hazardous iniury rates and acceptance of hepatitis B immunisation. $\mathcal{F}$ Soc Occup Med $1990 \cdot 40 \cdot 92-3$

9 Jeffries DJ. Zidovudine after occupational exposure to HIV. BMF 1991;302: 1349-51.

10 Brown EM, Caul EO, Roome APCG, Glover SC, Reeves DS, Harling CC. Zidovudine after occupational exposure to HIV. BMJ 1991;303:990

11 Lange JMA, Boucher CAB, Hollak CEM, Wiltink EHH, Reiss P, Van Royen $\mathrm{EA}$, et al. Failure of zidovudine prophylaxis after accidental exposure to HIV-1. N Engl F Med 1990;322:1375-7.

12 Looke DFM, Grove DI. Failed prophylactic zidovudine after needlestick injury. Lancet 1990;335:1280.

13 Tait DR, Pudifin DJ, Gathiram V, Windsor IM. Zidovudine after occupational exposure to HIV. BMf 1991;303:581.

14 Miller PJ, Farr BM. A study of the rate of postexposure human immunodeficiency virus testing in a hospital requiring written informed consent. fOccup Med 1989;31:524-7.

15 Miller R, Bor R. AIDS: a guide to clinical counselling. London: Science Press,

16 Bor R, Miller R, Johnson M. A testing time for doctors: counselling patients before an HIV test. $B M F$ 1991;303:905-7.

(Accepted 13 February 1992)
Childhood Cancer

Research Group,

University of Oxford,

Oxford OX2 6HJ

M M Hawkins,

epidemiologist

L M Kinnier Wilson, medical research officer

M H N Potok, computer

programmer

M D Anderson Cancer Center, University of Texas, USA

M A Stovall, radiation physicist

Royal Manchester Children's Hospital, Pendlebury, Manchester H B Marsden, professor of paediatric pathology

St Bartholomew's Hospital, London EC1

$\mathrm{J}$ E Kingston, consultant paediatric oncologist

Hospital for Sick Children, Great Ormond Street, London

$\mathrm{J} M$ Chessells, professor of

haematology and oncology

Correspondence to: $\mathrm{Dr}$ Hawkins.

BMJ 1992;304:951-8

\title{
Epipodophyllotoxins, alkylating agents, and radiation and risk of secondary leukaemia after childhood cancer
}

\author{
M M Hawkins, L M Kinnier Wilson, M A Stovall, H B Marsden, M H N Potok, J E Kingston, \\ J M Chessells
}

\section{Abstract}

Objective-To investigate the incidence and aetiology of secondary leukaemia after childhood cancer in Britain.

Design-Cohort study and a case-control study.

Setting-Britain and population based National Register of Childhood Tumours.

Subjects-Cohort of 16422 one year survivors of childhood cancer diagnosed in Britain between 1962 and 1983, among whom 22 secondary leukaemias were observed. A case-control study of 26 secondary leukaemias observed among survivors of childhood cancer diagnosed in Britain between 1940 and 1983; 96 controls were selected matched for sex, type of first cancer, age at first cancer, and interval to diagnosis of secondary leukaemia.

Main outcome measures-Dose of radiation averaged over patients' active bone marrow and total accumulated dose of epipodophyllotoxins, alkylating agents, vinca alkaloids, antimetabolites, and antibiotics $\left(\mathrm{mg} / \mathrm{m}^{2}\right)$ given for the original cancer.

Results - Cumulative risk of secondary leukaemia within the cohort did not exceed $0.5 \%$ over the initial five years beyond one year survival, except that after non-Hodgkin's lymphomas $1.4 \%$ of patients developed secondary leukaemia. Corresponding figure for patients treated for non-Hodgkin's lymphomas in the early 1980 s was $4 \%$. The relative risk of secondary leukaemia increased significantly with exposure to epipodophyllotoxins and dose of radiation averaged over patients' active bone marrow. Ten patients developed leukaemia after having an epipodophyllotoxin-teniposide in nine cases, etoposide in one. Chromosomal translocations involving 11q23 were observed relating to two secondary leukaemias from a total of six for which there were successful cytogenetic studies after administration of an epipodophyllotoxin.

Conclusions-Epipodophyllotoxins acting alone or together with alkylating agents or radiation seem to be involved in secondary leukaemia after childhood cancer.

\section{Introduction}

An excess of leukaemia has been observed after treatment of a variety of adult ${ }^{1-6}$ and childhood cancers. ${ }^{78}$ Case-control studies have identified specific groups of cytotoxic drugs that are associated with an increased risk of secondary leukaemias ${ }^{9-12}$; these and other studies have particularly identified alkylating agents as being associated with an increased risk of secondary leukaemia after adult and childhood cancers. Radiation exposure is undoubtedly involved in some leukaemias. ${ }^{13}$ There have also been suggestions that the epipodophyllotoxins may be related to an increased risk of subsequent leukaemias. ${ }^{14-21}$ We report the results of a population based cohort study and a casecontrol study carried out $(a)$ to estimate the absolute risk of secondary leukaemia after childhood cancer in Britain, and $(b)$ to determine those aspects of treatment related to an increased relative risk of secondary leukaemia.

\section{Methods}

PATHOLOGICAL CONFIRMATION OF NEOPLASMS

Each case included in the case-control study had representative slides of both the first and second neoplasms centrally reviewed and confirmed by a paediatric histopathologist (HBM). In addition, each possible occurrence of leukaemia after an initial leukaemia or non-Hodgkin's lymphoma was centrally reviewed by a haematologist (JMC). For each control we obtained the definitive pathology report(s) confirming the diagnosis concerned. For those patients included in the cohort study who did not develop a secondary leukaemia almost all diagnoses were histologically verified except for $4 \%$ of the leukaemias, $9 \%$ of the central nervous system tumours, and $8 \%$ of the retinoblastomas, which were based on blood counts, radiology or scans, and observation under anaesthesia respectively.

\section{COHORT STUDY}

From the population based National Register of Childhood Tumours maintained by the Childhood Cancer Research Group we identified children aged under 15 years who were diagnosed with cancer between 1962 and 1983 while resident in Britain and who subsequently survived at least one year. Entry to the study occurred one year after diagnosis, and patients exited when the first of one of the following occurred: a secondary leukaemia was diagnosed; the 
patient died; the date of last follow up was reached. A specifically designed follow up study was carried out by writing to the general practitioners of all eligible patients who were not known to have died asking about the possible development of a second primary neoplasm. To ensure that our ascertainment of secondary leukaemia was complete all patients not known to have died were flagged at the NHS central register, which should ensure the automatic notification of any deaths or cancers registered for flagged patients. For patients known to have died we routinely obtained the general practitioners' notes, which were inspected for any evidence that a secondary leukaemia had been diagnosed. In addition, through our close links with the United Kingdom Children's Cancer Study Group consultants at the main centres treating childhood cancer in Britain directly informed us of second primary neoplasms diagnosed in their patients.

For patients who were alive and not diagnosed with secondary leukaemia the study end date was the date the general practitioner completed the questionnaire indicating that the patient was alive and had never been diagnosed with a secondary leukaemia. Expected numbers of leukaemias were calculated on the basis of rates of 'occurrence of these diseases in the general population of England and Wales; the Office of Population Censuses and Surveys supplied a magnetic tape with the relevant information. Sex, age, and calendar period specific rates were applied to corresponding person years of observation. We assumed that the observed number of secondary leukaemias approximated to a Poisson distribution with a mean equal to the corresponding number expected from general population rates. Tests of significance and confidence intervals for relative risks were based on exact Poisson methods. ${ }^{22}$ Tests of statistical significance were two tailed unless stated to the contrary. The cumulative risks of secondary leukaemia were estimated by standard Kaplan-Meier techniques. ${ }^{23}$

In our national register of secondary neoplasms after childhood cancer we do not allow for the occurrence of secondary lymphoblastic leukaemia after either an initial lymphoblastic leukaemia or a non-Hodgkin's lymphoma. Therefore, to ensure that observed and expected numbers were comparable we excluded lymphoblastic leukaemia from the population rates used for calculating expected numbers of leukaemias after these two initial childhood neoplasms. Moreover, because the few secondary leukaemias observed within the cohort were intensively followed up there were few with an unspecified cell type. In contrast, the general population rates of leukaemia include a substantial fraction of leukaemias of unspecified cell type. Therefore, we distributed the unspecified leukaemias occurring in the general population between the specified cell types in proportion to the relative frequency of the specified cell types. In this way we attempted to produce estimates of relative risk that were as free of bias as possible.

\section{CASE-CONTROL STUDY}

Although our study was population based for neoplasms diagnosed in 1962 or later, there were also records relating to nearly 2000 patients diagnosed between 1940 and 1962 and treated at particular centres for which we have complete lists of patients who survived at least three years. Therefore, for the case-control study we did not restrict the initial childhood cancer to those diagnosed between 1962 and 1983. Cases of secondary leukaemia occurring between one and three years after diagnosis and more than three years after diagnosis of the initial childhood neoplasm were matched with potential controls diagnosed between 1962 and 1983 and between 1940 and 1983 respectively. Corresponding to each case, we attempted to select four controls matched for sex, histological type of first cancer, and age at first cancer. In addition, controls must have survived free of any second primary neoplasm at least as long as the interval between the first primary neoplasm and secondary leukaemia in the corresponding case.

Comparisons between cases and controls were carried out by standard conditional logistic regression methods..$^{24}$ The EGRET epidemiological software ${ }^{25}$ was used to analyse the case-control study, some analyses including the stepwise model fitting procedures provided. All tests of statistical significance were two tailed unless stated to the contrary.

\section{Active bone marrow-radiation dosimetry}

To estimate the averaged absorbed radiation dose the active bone marrow was divided into 148 anatomical parts. Location and relative weight of the active bone marrow in each part were based on the data of Christy. ${ }^{26}$ Christy divided the active bone marrow into 14 partitions, and we further subdivided these partitions assuming uniform distribution of active bone marrow within each of the original partitions. A computer program described mathematically a three dimensional patient of any size with the active bone marrow located appropriately for age. Each treatment field was located on the three dimensional phantom. The dose outside the field was calculated by using data measured in a water phantom. The dose inside a treatment field was derived from standard radiotherapy data. The dose to each part was calculated and total averaged active bone marrow dose estimated as a weighted average to these parts. Other studies have compared this method of dosimetry with measurements in anthropomorphic phantoms and found agreement. ${ }^{27}$

\section{Chemotherapy dosimetry}

For those patients who received cytotoxic drug therapy we subdivided the treatment into cycles or courses of treatment. For each drug received within each cycle we recorded the dates of the start and end of administration, total dose received per unit surface area, and the route of administration. For analysis we simply summed across cycles the total dose received per unit surface area for each drug received. Because of the relatively small number of cases and the heterogeneity of multiple agent therapy used to treat patients included in the study it was necessary to consider drugs in terms of meaningful aetiological groups rather than analyse single agents. The groups of drugs used most frequently in the study were alkylating agents, vinca alkaloids, antibiotics, antimetabolites, and epipodophyllotoxins. The question of how to combine the exposure to single agents into a measure of exposure to drugs within a particular aetiological group needs to be addressed.

Because of the uncertainty surrounding the relative leukaemogenicity of different agents within specific groups it was considered wise to use more than one method of combining exposures. Tucker and colleagues proposed one method of combining such drugs that assumes that all drugs within an aetiological group have equal leukaemogenic potency within the corresponding third of their respective dose distributions. ${ }^{12}$ For example, Tucker's "alkylating score" was obtained by assigning to patients a score of $0,1,2$, or 3 for each alkylating agent, depending on whether they received none or occupied the lower, middle, or upper third of the distribution of total doses per unit of surface area for that agent. The alkylating score for each patient was the sum of the scores for each alkylating agent given to that patient. We used Tucker's approach but, in addition, we also used an approach based on the simple

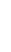


assumption that all agents within a particular group share an equal leukaemogenic potency for a specified amount of drug given per unit of surface area. For ease of communication we term these two methods of measuring exposure to particular groups of drugs the "SCORE" and "EQUIVALENT $\mathrm{mg} / \mathrm{m}^{2}$ " methods respectively.

\section{Results}

Table I gives a cross tabulation of the types of initial neoplasms and types of secondary leukaemia observed in the cohort and case-control studies. Twenty six secondary leukaemias were included in the casecontrol study, including the four patients whose initial childhood neoplasm was diagnosed before 1962 and excluded from the cohort study. Only relatively recently have reliable techniques become available to distinguish different types of leukaemia within an individual patient, and this is reflected by only one of the patients developing two distinct leukaemias being diagnosed with the first leukaemia before 1980 .

\section{COHORT STUDY}

Among 16422 patients who survived at least one year after being diagnosed with a childhood neoplasm in Britain between 1962 and 1983 inclusive, 22 secondary leukaemias were observed, of which 16 were acute myeloid in type. The interval between diagnosis of the initial childhood neoplasm and the subsequent leukaemia was consistently under six years for patients in the cohort study. For the entire cohort 2.72 secondary leukaemias were expected, yielding a relative risk of 8 (table II). Table II shows that the absolute risk of secondary leukaemia was greatest after nonHodgkin's lymphomas, with an estimated cumulative risk of $1.4 \%$ at five years from one year survival. This corresponds to 112 times the expected number of leukaemias. The mean follow up period beyond one year survival for the entire cohort was $7 \cdot 7$ years.

Table II also shows the variation in the relative risks of subsequent myeloid or monocytic leukaemias after different initial childhood neoplasms. Seventeen acute myeloid or monocytic leukaemias were observed, which was 17 times the number expected. The relative risk of myeloid or monocytic leukaemia was greatest after non-Hodgkin's lymphomas, at 129 times the number expected.

The treatment information available on the generality of the cohort was poor compared with that collected within the case-control study; furthermore, it was incomplete, in that there were 4338 patients $(26 \%$ of the cohort) for whom whether they had received radiotherapy or chemotherapy, or both, was unknown. Therefore, it was considered unwise to attempt to estimate the risk of secondary leukaemia for separate treatment groups.

Table III gives the variation in the risk of a subsequent leukaemia generally, and myeloid or monocytic leukaemia specifically, in relation to the decade $(1962-9,1970-9,1980-3)$ in which the initial childhood neoplasm was first treated. There was clear evidence of an increased risk of subsequent leukaemias among those treated more recently. The cumulative risks of secondary leukaemia after non-Hodgkin's lymphomas five years from entry after treatment in $1962-9,1970-9$, and $1980-3$ were $0 \%, 0.5 \%$, and $4 \%$ respectively. Although these associations were strong and undoubtedly largely real, an element of artefact was involved. As mentioned above, only relatively recently have the techniques been available to identify the occurrence of secondary leukaemia after initial leukaemia. Also it is possible that, in the absence of expert knowledge of paediatric histopathology, secondary non-lymphoid leukaemia after nonHodgkin's lymphoma was sometimes in the past ascribed to a progression of the original disease.

\section{CASE-CONTROL STUDY}

There were 26 cases included, and we attempted to select four controls per case. In fact, we were unable to select eight controls because even after some relaxation

TABLE I-Composition of cohort and case-control studies in terms of initial childhood neoplasms, types of secondary leukaemia, and intervals between diagnoses for cases

\begin{tabular}{|c|c|c|c|c|c|}
\hline \multirow[b]{2}{*}{ Type of initial childhood neoplasm } & \multirow[b]{2}{*}{$\begin{array}{l}\text { No of one year } \\
\text { survivors included }\end{array}$} & \multicolumn{4}{|c|}{ Interval (years) between diagnosis of first childhood cancer and secondary leukaemia } \\
\hline & & $\begin{array}{l}\text { Acute myeloid } \\
\text { leukaemia }\end{array}$ & $\begin{array}{l}\text { Acute monocytic } \\
\text { leukaemia }\end{array}$ & $\begin{array}{c}\text { Acute lymphocytic } \\
\text { leukaemia }\end{array}$ & $\begin{array}{l}\text { Acute leukaemia not } \\
\text { otherwise specified }\end{array}$ \\
\hline $\begin{array}{l}\text { Acute lymphocytic leukaemia } \\
\text { Hodgkin's disease } \\
\text { Non-Hodgkin's lymphoma } \\
\text { Astrocytoma and medulloblastoma } \\
\text { Neuroblastoma } \\
\text { Other }\end{array}$ & $\begin{array}{r}4671 \\
1046 \\
699 \\
2258 \\
712 \\
7036\end{array}$ & $\begin{array}{c}2 \cdot 8,3 \cdot 0,4 \cdot 3 \\
4 \cdot 3,4 \cdot 9 \\
3 \cdot 0,3 \cdot 2,4 \cdot 5,4 \cdot 7,5 \cdot 0,3 \cdot 0 \\
1 \cdot 5,3 \cdot 2,3 \cdot 8,4 \cdot 2,27 \cdot 2 \star \\
2 \cdot 5\end{array}$ & $13 \cdot 1^{\star} \dagger$ & $\begin{array}{c}5 \cdot 1 \\
2 \cdot 6, \ddagger 4 \cdot 7, \S 7 \cdot 6 \star\end{array}$ & $\begin{array}{c}5 \cdot 8 \\
2 \cdot 3,19 \cdot 2^{\star}\end{array}$ \\
\hline Total & 16422 & 17 & 2 & 4 & 3 \\
\hline
\end{tabular}

TABLE II-Absolute and relative risks of leukaemia after childhood neoplasms by diagnosis: cohort study

\begin{tabular}{|c|c|c|c|c|c|c|c|c|c|c|}
\hline \multirow[b]{2}{*}{ Diagnosis } & \multicolumn{5}{|c|}{ Myeloid or monocytic leukaemia } & \multicolumn{5}{|c|}{ All types of leukaemia } \\
\hline & $\begin{array}{l}\% \text { Cumulative } \\
\text { risk by } 5 \text { years } \\
\text { from entry (SE) }\end{array}$ & $\begin{array}{c}\text { No of } \\
\text { observed }(\mathrm{O}) \\
\text { leukaemias }\end{array}$ & $\begin{array}{c}\text { No of } \\
\text { expected }(E) \\
\text { leukaemias }\end{array}$ & $\begin{array}{c}\text { Relative risk }(\mathrm{O} / \mathrm{E}) \\
(95 \% \text { confidence interval })\end{array}$ & p Value & $\begin{array}{l}\% \text { Cumulative } \\
\text { risk by } 5 \text { years } \\
\text { from entry (SE) }\end{array}$ & $\begin{array}{c}\text { No of } \\
\text { observed }(\mathbf{O}) \\
\text { leukaemias }\end{array}$ & $\begin{array}{c}\text { No of } \\
\text { expected (E) } \\
\text { leukaemias }\end{array}$ & $\begin{array}{c}\text { Relative risk }(\mathrm{O} / \mathrm{E}) \\
(95 \% \text { confidence interval })\end{array}$ & p Value \\
\hline Acute lymphocytic leukaemia & $0 \cdot 1(0 \cdot 1)$ & 4 & $0 \cdot 17$ & 24 (7 to 61$)$ & $<0.001$ & $0 \cdot 1(0 \cdot 1)$ & 4 & $0 \cdot 21 \dagger$ & $19(5$ to 49$)$ & $<0.001$ \\
\hline Hodgkin's disease & $0 \cdot 2(0 \cdot 2)$ & 2 & 0.09 & $22(3$ to 81$)$ & 0.008 & $0 \cdot 4(0 \cdot 2)$ & 3 & 0.22 & $14(3$ to 40$)$ & 0.002 \\
\hline Non-Hodgkin's lymphoma & $1.4(0.5)$ & 6 & 0.05 & $129(47$ to 281$)$ & $<0.001$ & $1.4(0.5)$ & 6 & $0.05 \dagger$ & $112(41$ to 244$)$ & $<0.001$ \\
\hline Astrocytoma and medulloblastoma & $0 \cdot 2(0 \cdot 1)$ & 4 & $0 \cdot 17$ & $23(6$ to 60$)$ & $<0.001$ & $0 \cdot 3(0 \cdot 1)$ & 5 & $0.49^{\circ}$ & $10(3$ to 24$)$ & $<0.001$ \\
\hline Neuroblastoma & $0 \cdot 2(0 \cdot 2)$ & 1 & $0 \cdot 04$ & $26(0 \cdot 6$ to 143$)$ & $0 \cdot 076$ & $0.5(0.3)$ & 2 & $0 \cdot 17$ & $11(1.4$ to 41$)$ & 0.028 \\
\hline Other & & 0 & $0 \cdot 47$ & 0 & & & 2 & 1.58 & $1(0 \cdot 1$ to 4$)$ & 0.936 \\
\hline All childhood neoplasms & $0.2(0.0)$ & 17 & 0.99 & 17 (10 to 28$)$ & $<0.001$ & $0.2(0.0)$ & 22 & $2 \cdot 72$ & $8(5$ to 12$)$ & $<0.001$ \\
\hline
\end{tabular}

$\star$ Expected numbers include that proportion of unspecified leukaemias corresponding to relative frequency of myeloid and monocytic leukaemia among all leukaemias with specified cell type (se Methods).

tExpected numbers of all types of leukaemias except lymphoid leukaemia (see Methods) 


\begin{tabular}{|c|c|c|c|c|c|c|c|}
\hline \multirow[b]{2}{*}{ Year initially treated } & \multirow[b]{2}{*}{$\begin{array}{l}\% \text { Cumulative risk of any } \\
\text { leukaemia by } 5 \text { years } \\
\text { from entry (SE) }\end{array}$} & \multicolumn{3}{|c|}{ Myeloid or monocytic leukaemia } & \multicolumn{3}{|c|}{ All types of leukaemia } \\
\hline & & $\begin{array}{c}\text { No of } \\
\text { observed }(\mathrm{O}) \\
\text { leukaemias }\end{array}$ & $\begin{array}{l}\text { No of } \\
\text { expected }(E) \\
\text { leukaemias }\end{array}$ & $\begin{array}{c}\text { Relative risk }(\mathrm{O} / \mathrm{E}) \\
(95 \% \text { confidence interval })\end{array}$ & $\begin{array}{c}\text { No of } \\
\text { observed }(\mathrm{O}) \\
\text { leukaemias }\end{array}$ & $\begin{array}{c}\text { No of } \\
\text { expected }(E) \\
\text { leukaemiast }\end{array}$ & $\begin{array}{c}\text { Relative risk }(\mathrm{O} / \mathrm{E}) \\
\text { (95\% confidence interval) }\end{array}$ \\
\hline $1962-9$ & 0 & 0 & 0.41 & 0 & 0 & 0.96 & 0 \\
\hline $1970-9$ & $0 \cdot 2(0 \cdot 1)$ & 5 & 0.47 & 11 (3 to 25$)$ & 10 & $1 \cdot 37$ & $7(4$ to 13$)$ \\
\hline $1980-3$ & $0 \cdot 4(0 \cdot 1)$ & 12 & 0.11 & 111 (58 to 195$)$ & 12 & 0.39 & 30 (16 to 53$)$ \\
\hline
\end{tabular}

$\mathrm{p}$ Value for linear

trend in cumulative/

relative risks

$<0.001$

$<0 \cdot 001$

$<0 \cdot 001$

^Expected numbers include that proportion of unspecified leukaemias corresponding to relative frequency of myeloid and monocytic leukaemia among all leukaemias with specified cell type (see Methods).

†Expected numbers of all types of leukaemia except lymphoid leukaemia after acute lymphocytic leukaemia and non-Hodgkin's lymphomas.

of the matching criteria there were no potential controls available. Therefore, our analysis was based on the 96 controls who were selected: 21 cases each had four controls, three cases each had three controls, one case had two controls, and one case had one control. All but six matched controls were selected from among potential controls with an age at diagnosis within a year of that of the case; in the remaining six controls this was relaxed to within three years. From a detailed examination of the clinical notes there were no genetic, familial, or other conditions identified among the cases or their first degree relatives that were known to predispose to leukaemia.

An initial summary of the results of the case-control study is given in table IV. Each broad category of treatment (radiotherapy only, chemotherapy only, both radiotherapy and chemotherapy) was separately associated with an increased relative risk of subsequent leukaemia in comparison with the reference category of neither radiotherapy nor chemotherapy. The significance level corresponding to radiotherapy only at least may be halved to give a one tailed test, because radiation is established as being associated with an increased risk of leukaemia.

Although it is apparent from table IV that radiotherapy was associated with an increased risk of subsequent leukaemia, further insight may be obtained by subdividing the study population according to dose of radiation averaged over the patients' active bone marrow. The results of this are given in table $\mathrm{V}$. There was evidence of a trend in the relative risk of subsequent leukaemia with increasing average dose of radiation received by the patients' active bone marrow. However, the estimates of relative risk associated with the specific levels of exposure were subject to wide $95 \%$ confidence intervals.

Chemotherapy was given to $69 \%$ and $55 \%$ of cases and controls respectively. Almost all of those patients receiving chemotherapy had multiple drugs: $94 \%$ and $79 \%$ of cases and controls respectively who received chemotherapy were given at least four different cytotoxic agents. Furthermore, as there was a wide spectrum of initial childhood neoplasms among the cases, and therefore among controls, the types and combinations of drugs used were very heterogeneous. However, the cytotoxic drugs given were mainly of the

TABLE IV - Distribution of cases and controls by treatment

\begin{tabular}{|c|c|c|c|c|}
\hline \multirow[b]{2}{*}{ Treatment } & \multicolumn{2}{|c|}{ No of patients } & \multirow{2}{*}{$\begin{array}{l}\text { Relative risk ( } 95 \% \\
\text { confidence interval) }\end{array}$} & \multirow[b]{2}{*}{$\mathrm{p}$ Value } \\
\hline & Cases & Controls & & \\
\hline \multirow{4}{*}{$\begin{array}{l}\text { Neither radiotherapy nor cytotoxic } \\
\text { drug therapy } \\
\text { Radiotherapy only } \\
\text { Cytotoxic drug therapy only } \\
\text { Both radiotherapy and cytotoxic } \\
\text { drug therapy }\end{array}$} & 1 & 16 & $1 \cdot 0$ & \\
\hline & 7 & 27 & $8.4(0.9$ to 81$)$ & 0.066 \\
\hline & 3 & 14 & $33 \cdot 6(1 \cdot 3$ to 884$)$ & 0.035 \\
\hline & 15 & 39 & $62 \cdot 9(3$ to 1368$)$ & $0 \cdot 008$ \\
\hline Total & 26 & 96 & & \\
\hline
\end{tabular}

following types: alkylating agents, antibiotics, antimetabolites, vinca alkaloids, or epipodophyllotoxins. Of those patients receiving chemotherapy, $77 \%, 51 \%$, $54 \%, 97 \%$, and $30 \%$ received at least one of each of these types of drug respectively.

The variations in relative risk of secondary leukaemia according to total dose of alkylating agents received are reported in table VI. As mentioned above, we quantified total exposure to particular groups of drugs in two ways: by scores and by equivalent $\mathrm{mg} / \mathrm{m}^{2}$. Both the scores and equivalent $\mathrm{mg} / \mathrm{m}^{2}$ method revealed significant $(p=0.003$ and 0.008 respectively) evidence of a trend in the relative risk of secondary leukaemia with increasing exposure to alkylating agents. Again, the estimates of relative risk corresponding to particular exposure levels had wide $95 \%$ confidence intervals.

Table VII shows the relative risk of secondary leukaemia according to the dose of epipodophyllotoxins received. There was very strong evidence of a trend $(\mathrm{p}<0.001)$ in the relative risk of subsequent leukaemia with dose of epipodophyllotoxins under both methods of quantifying total exposure.

The relative risk of secondary leukaemia increased with increasing dose of vinca alkaloids under both methods of quantifying exposure, but this vanished after controlling for exposure to the other three aspects of treatment. There was no evidence of a statistically significant relation between exposure to either antibiotics or antimetabolites and the relative risk of secondary leukaemia, irrespective of the method used to quantify exposure.

There was no evidence of any statistically significant non-linear variation in the relative risk of subsequent leukaemia with exposure to any of the aspects of treatment concerned, irrespective of the method of quantifying exposure to particular groups of drugs. Therefore, in all subsequent analyses we fitted only a single parameter corresponding to a linear trend with each particular aspect of treatment. Table VI shows that the evidence of a trend in the relative risk of leukaemia with increasing exposure to alkylating agents was not quite significant after controlling for exposure to radiation and epipodophyllotoxins. However, a one tailed test, half the $p$ value given in table VI, was significant $(p=0.044)$ when quantifying exposure using scores and almost significant $(p=0.086)$ when using the equivalent $\mathrm{mg} / \mathrm{m}^{2}$ method. Table $\mathrm{V}$ shows that the trend in the relative risk of secondary leukaemia with increased averaged active bone marrow exposure to radiation remained after controlling for exposure to both epipodophyllotoxins and alkylating agents. Similarly, in table VII there is evidence that the trend in the relative risk of secondary leukaemia with increased exposure to epipodophyllotoxins remained after controlling for exposure to both radiation and alkylating agents.

The results given above, concerning the four elements of treatments that were each separately related to an increased relative risk of subsequent 


\begin{tabular}{|c|c|c|c|c|c|c|}
\hline \multirow[b]{3}{*}{ Active bone marrow dose (rad) } & \multirow[b]{3}{*}{$\begin{array}{l}\text { Values entered } \\
\text { in model }\end{array}$} & \multicolumn{2}{|c|}{ No of patients } & \multicolumn{3}{|c|}{ Relative risk ( $95 \%$ confidence interval) } \\
\hline & & \multirow[b]{2}{*}{ Cases } & \multirow[b]{2}{*}{ Controls } & \multirow[b]{2}{*}{ Trend } & \multicolumn{2}{|c|}{ Adjusted trend $\dagger$} \\
\hline & & & & & A & B \\
\hline $\begin{array}{l}\text { Incomplete dose details } \\
0 \\
1-499 \\
500-999 \\
1000-1499 \\
\geqslant 1500\end{array}$ & $\begin{array}{l}0 \\
1 \\
2 \\
3 \\
4\end{array}$ & $\begin{array}{r}1 \\
4 \\
10 \\
5 \\
3 \\
3\end{array}$ & $\begin{array}{r}4 \\
30 \\
42 \\
8 \\
7 \\
5\end{array}$ & $\begin{array}{l}1 \\
2 \cdot 1(1 \cdot 1 \text { to } 3 \cdot 9) \\
4 \cdot 4(1 \cdot 3 \text { to } 15 \cdot 0) \\
9 \cdot 4(1 \cdot 5 \text { to } 58 \cdot 0) \\
19 \cdot 8(1 \cdot 7 \text { to } 224 \cdot 4) \\
p=0.012^{\star}\end{array}$ & $\begin{array}{c}1 \\
2 \cdot 1 \\
4 \cdot 4 \\
9 \cdot 3 \\
19 \cdot 5 \\
\mathrm{p}=0 \cdot 023\end{array}$ & $\begin{array}{c}1 \\
2 \cdot 0 \\
4 \cdot 0 \\
8 \cdot 1 \\
16 \cdot 3 \\
\mathrm{p}=0 \cdot 026\end{array}$ \\
\hline Total & & 26 & 96 & & & \\
\hline
\end{tabular}

*Significance level associated with likelihood ratio statistic corresponding to model with one parameter for trend.

†Adjusted for dose of alkylating agents and epipodophyllotoxins; relative risks given correspond to lowest level of each of these factors. Column A: doses of drugs measured in terms of score. Column B: doses of drugs measured in terms of total equivalent $\mathrm{mg} / \mathrm{m}^{2}$.

TABLE VI-Relative risks of leukaemia by dose of alkylating agents: case-control study

\begin{tabular}{|c|c|c|c|c|c|}
\hline & \multirow{2}{*}{$\begin{array}{l}\text { Values entered } \\
\text { in model }\end{array}$} & \multicolumn{2}{|c|}{ No of patients } & \multicolumn{2}{|c|}{ Relative risk ( $95 \%$ confidence interval) } \\
\hline & & Cases & Controls & Trend & Adjusted trend $\dagger$ \\
\hline \multicolumn{6}{|l|}{ Total score: } \\
\hline 0 & 0 & 11 & 56 & 1 & 1 \\
\hline 1 & 1 & 2 & 8 & $1.7(1.2$ to 2.4$)$ & 1.5 \\
\hline 2,3 & 2 & 3 & 19 & $2.7(1.3$ to 5.7$)$ & $2 \cdot 1$ \\
\hline 4 & 3 & 4 & 6 & $4.6(1.5$ to 13.4$)$ & $3 \cdot 1$ \\
\hline 5 & 4 & 3 & 4 & $7.5(1.8$ to 31.9$)$ & $4 \cdot 6$ \\
\hline 6 & 5 & 3 & 3 & $12.5(2 \cdot 1$ to 75.9$)$ & $6 \cdot 7$ \\
\hline \multirow{2}{*}{\multicolumn{6}{|c|}{ Total equivalent $\mathrm{mg} / \mathrm{m}^{2}$ : }} \\
\hline 0 & 0 & 11 & & & \\
\hline $1-4399$ & 1 & 2 & 12 & $1.6(1.1$ to $2 \cdot 4)$ & 1.4 \\
\hline $4400-8999$ & 2 & 4 & 10 & $2.7(1.2$ to 5.9$)$ & $2 \cdot 0$ \\
\hline $9000-13299$ & 3 & 4 & 10 & $4.5(1.4$ to $14 \cdot 5)$ & $2 \cdot 8$ \\
\hline$\geqslant 13300$ & 4 & 5 & 8 & $7 \cdot 4(1 \cdot 6$ to $35 \cdot 2)$ & $4 \cdot 0$ \\
\hline & & & & $\mathrm{p}=0.008^{\star}$ & $\mathrm{p}=0.172 \ddagger$ \\
\hline
\end{tabular}

96

* Significance level associated with likelihood ratio statistic corresponding to model with one parameter for trend.

†Adjusted for active bone marrow radiation dose and epipodophyllotoxins; relative risks given correspond to lowest level of each of these factors.

¥Significance level associated with likelihood ratio statistic comparing model with two parameters (active bone marrow radiation dose and dose of epipodophyllotoxins) versus that with three parameters (extra parameter corresponding to dose of alkylating agent).

TABLE VII - Relative risks of leukaemia by dose of epipodophyllotoxins: case-control study

\begin{tabular}{|c|c|c|c|c|c|}
\hline & \multirow{2}{*}{$\begin{array}{l}\text { Values entered } \\
\text { in model }\end{array}$} & \multicolumn{2}{|c|}{ No of patients } & \multicolumn{2}{|c|}{ Relative risk ( $95 \%$ confidence interval) } \\
\hline & & Cases & Controls & Trend & Adjusted trend $\dagger$ \\
\hline \multicolumn{6}{|l|}{ Total score: } \\
\hline 0 & 0 & 16 & 85 & 1 & 1 \\
\hline 1 & 1 & 2 & 5 & $3.8(1.6$ to 9.4$)$ & $2 \cdot 9$ \\
\hline 2 & 2 & 4 & 4 & $14 \cdot 8(2 \cdot 5$ to 88.4$)$ & $8 \cdot 4$ \\
\hline 3 & 3 & 4 & 2 & $56.9(3.9$ to 830.7$)$ & $24 \cdot 5$ \\
\hline \multirow{2}{*}{\multicolumn{6}{|c|}{ Total equivalent $\mathrm{mg} / \mathrm{m}^{2}$ : }} \\
\hline & & & & & \\
\hline 0 & 0 & 16 & 85 & 1 & 1 \\
\hline $1-750$ & 1 & 2 & 5 & $3.4(1.5$ to 7.8$)$ & $2 \cdot 6$ \\
\hline $751-1200$ & 2 & 3 & 4 & $11 \cdot 6(2 \cdot 2$ to $61 \cdot 1)$ & $6 \cdot 6$ \\
\hline$\geqslant 1201$ & 3 & 5 & 2 & $39 \cdot 4(3 \cdot 3$ to $477 \cdot 3)$ & $17 \cdot 1$ \\
\hline & & & & $\mathrm{p}<0.001^{\star}$ & $\mathrm{p}=0.006 \ddagger$ \\
\hline
\end{tabular}

* Significance level associated with likelihood ratio statistic corresponding to model with one parameter for trend.

†Adjusted for active bone marrow radiation dose and alkylating agents; relative risks given correspond to lowest level of each of these factors.

$\ddagger$ Significance level associated with likelihood ratio statistic comparing model with two parameters (active bone marrow radiation dose and dose of alkylating agents) versus that with three parameters (extra parameter corresponding to dose of epipodophyllotoxins).

leukaemia, were confirmed when a stepwise regression model building procedure was adopted in which the most significant parameter, according to a score test, was added to the model until no parameter was significant at 0.05 . The outcome of this procedure was - under both methods of quantifying exposure to drugs - that the final model included two parameters, one corresponding to a linear trend with the dose of radiation averaged over patients' active bone marrow and the other corresponding to a linear trend with epipodophyllotoxin exposure.

For the 10 secondary leukaemias occurring after treatment with an epipodophyllotoxin in our study we ascertained whether any cytogenetic studies had been carried out and in particular whether any abnormality involving 1 1q23 had been found. For three patients no cytogenetic studies had been carried out, and for one patient studies were attempted but no dividing cells were obtained. Cytogenetic studies were successful in relation to six patients with secondary leukaemia: four were normal and two revealed a chromosomal translocation involving 11q23. One patient who developed secondary acute lymphoblastic leukaemia with $t(4 ; 11)$ (q21,q23) after neuroblastoma has been the subject of a separate report. ${ }^{28}$ Another patient developed secondary acute myeloid leukaemia with $t(11 ; 16)(\mathrm{q} 23, \mathrm{p} 13)$ after non-Hodgkin's lymphoma and has also been described. ${ }^{29}$ There were no other chromosomal abnormalities found, and in particular none involving chromosome 5 or 7 . 


\section{Discussion}

There was strong evidence from our data that the relative risk of secondary leukaemia increases with increasing dose of epipodophyllotoxins and with increasing dose of radiation averaged over the active bone marrow of patients as a result of radiotherapy. There was also evidence of an increase in the relative risk of second leukaemia with increasing dose of alkylating agents.

There have been previous suggestions that the epipodophyllotoxins might be related to an increased risk of subsequent leukaemia. In particular, evidence has emerged from the comparison of two series of children treated for acute lymphoblastic leukaemia. In one series, from St Jude's Children's Research Hospital, ${ }^{16}$ at six years from diagnosis the cumulative risks of acute myeloid leukaemia were $19 \cdot 1 \%$ and $2 \cdot 9 \%$ among patients with and without a $\mathrm{T}$ cell immunophenotype respectively. Most patients received an epipodophyllotoxin, including all those with $\mathrm{T}$ cell acute lymphoblastic leukaemia and, most notably, 12 of the 13 patients who developed secondary acute myeloid leukaemia. A preliminary communication from the other series, ${ }^{17}$ arising from the Dana Farber Cancer Institute, the Children's Hospital in Boston, and the University of Rochester Cancer Centre, based on a similar number of children followed up for a similar interval reported only two patients developing acute myeloid leukaemia, only one case diagnosed in a patient with a previous $\mathrm{T}$ cell immunophenotype. Epipodophyllotoxins were never used to treat acute lymphoblastic leukaemia in this latter series.

There is also evidence of a relation between the administration of epipodophyllotoxins and an increased risk of acute non-lymphoid leukaemia after non-small cell carcinoma of the lung,$^{14}$ neuroblastoma, ${ }^{15}$ solid tumours of childhood, ${ }^{18} 19$ and germ cell tumours. ${ }^{20} \mathrm{~A}$ recent review ${ }^{21}$ identified 37 patients who had developed acute non-lymphocytic leukaemia after epipodophyllotoxins. An observation made in relation to a substantial number of these apparently epipodophyllotoxin related acute non-lymphoid leukaemias was that there seemed to be an associated chromosomal abnormality involving 11q23, 14161820213031 suggesting the possibility of a specific mechanism of induction. The cytogenetic abnormalities commonly associated with secondary acute non-lymphoid leukaemia involve chromosomes 5 and $7 . .^{22-35}$

A remaining uncertainty in interpreting the association between the relative risk of subsequent leukaemia and degree of exposure to epipodophyllotoxins as being causal in our data relates to other treatment received by the patients given epipodophyllotoxins and developing a secondary leukaemia. As a result of there being relatively few patients with secondary leukaemia in our study, and considerable heterogeneity of drug combinations used, we were unable to examine the variation in relative risk of secondary leukaemia and the dose of individual drugs. Therefore, it is conceivable that there was some other important aspect of the cocktail of drugs and radiotherapy received by these patients that affected the risk of secondary leukaemia.

Each patient developing leukaemia after an epipodophyllotoxin also recieved at least one alkylating agent and most received at least two. For example, cyclophosphamide and lomustine were received by nine and six, respectively, of the 10 patients who developed leukaemia after administration of an epipodophyllotoxin. Lomustine, an alkylating agent (nitrosourea), is a potent leukaemogen. ${ }^{46}$ Cyclophosphamide, another alkylating agent, has long been associated with secondary leukaemia, although it seems to be less leukaemogenic than most other alkylating agents. ${ }^{107-39}$ Additionally, radiotherapy was used to treat the original childhood cancer in eight of these 10 patients.
However, despite these uncertainties, given the strong dose-response from our data, the support of associations from other studies linking the epipodophyllotoxins and secondary leukaemia, and the occurrence of balanced translocations involving 11q23 corresponding to a third of the secondary leukaemias for which there were successful chromosome studies after an epipodophyllotoxin, the cumulative evidence favours interpreting our data as indicating a dominant effect of either the epipodophyllotoxins acting alone or epipodophyllotoxins acting together with alkylating agents or radiation in the development of secondary leukaemia.

\section{ABSOLUTE RISK OF SECONDARY LEUKAEMIA}

Our cohort study indicates that the absolute risk of secondary leukaemia after an initial childhood neoplasm is low except after non-Hodgkin's lymphoma. Pui et al ${ }^{1819}$ have reported the low risk of myeloid neoplasia after solid tumours in childhood, and the only notable discrepancy between their series and ours is the relatively high risk of secondary leukaemia after non-Hodgkin's lymphomas treated in Britain in the early 1980s. The considerable risk of second malignancy after treatment of non-Hodgkin's lymphoma and $\mathrm{T}$ cell leukaemia with the United Kingdom Children's Cancer Study Group regimens during this period has been reported.$^{40}$ This increased risk is probably explained to a large extent by the epipodophyllotoxins that were given in association with alkylating agents and radiotherapy to treat nonHodgkin's lymphomas in Britain during this period. Under the United Kingdom Children's Cancer Study Group's clinical trial protocol used to treat patients with non-Hodgkin's lymphomas between 1977 and $1983^{41}$ a patient who did not relapse might have received a total dose of teniposide of between 800 and $900 \mathrm{mg} / \mathrm{m}^{2}$. Table VII shows that this range of doses is associated with a risk of secondary leukaemia about 12 times that among patients not exposed to epipodophyllotoxins.

The only epipodophyllotoxin used to treat all but one of the 10 patients developing secondary leukaemia after an epipodophyllotoxin was teniposide; one patient developed secondary leukaemia after etoposide. Laboratory work has indicated that although teniposide and etoposide have similar kinetics for DNA break formation and repair and similar relations between DNA breakage and cytotoxicity, teniposide is around 10 times more potent than etoposide in causing DNA damage in vitro and in vivo. ${ }^{42} 43$

In our data the association between exposure to alkylating agents and the relative risk of secondary leukaemia was of only borderline significance after controlling for exposure to radiation and epipodophyllotoxins. However, this should not be interpreted as indicating that alkylating agents were not involved in the development of secondary leukaemia. It seems likely that this resulted from the relatively small number of cases in our study and an association with exposure to alkylating agents in aggregate, which was weaker than that with exposure to epipodophyllotoxins in aggregate. Cyclophosphamide was by far the most common alkylating agent used to treat patients in our study and there has been previous evidence suggesting that this is one of the weaker leukaemogens among the alkylating agents. ${ }^{10}$ 37-39

In the Late Effects Study Group case-control study of leukaemia after childhood cancer a very different pattern of treatment with alkylating agents was observed from that seen in our study, procarbazine and nitrogen mustard being the most commonly used alkylating agents in both cases and controls. ${ }^{12}$ Furthermore, there was no mention in the Late Effects Study Group report of the use of epipodophyllotoxins. Both 
of these differences from our study are likely to explain to some extent the apparent different findings with regard to alkylating agents. The different pattern of alkylating agents used in the Late Effects Study Group study arose from the fact that the first cancers in the patients who developed a secondary leukaemia were very dissimilar to those observed in our study. For example, in 20 cases out of a total of 25 in the Late Effects Study Group case-control study the first cancer was Hodgkin's disease, Wilms's tumour, or Ewing's sarcoma. ${ }^{12}$

The Late Effects Study Group study found no evidence of an association between the dose of radiation averaged over patient's active bone marrow and the relative risk of leukaemia. This apparent discrepancy with our study may have arisen as a result of the method of estimating the average active bone marrow dose of radiation received. Although a comparable estimation method was used in both studies, it is possible that because of the substantially different mix of first cancers that preceded leukaemia in the two studies, and the differing therapeutic practices prevailing between the studies, that the radiotherapy fields used for patients included in our study may have resulted in a lower average exposure of larger volumes of bone marrow than the fields used in the Late Effects Study Group study. If so, the leukaemia rate might have been higher in our study because for a specified dose averaged over a patient's entire bone marrow less killing of cells might occur and therefore more cells would be susceptible to leukaemogenic transformation. This hypothesis has been suggested as a possible explanation of the higher relative risk of leukaemia after Hodgkin's disease ${ }^{9}$ than after cervical cancer. ${ }^{44}$

\section{TOWARDS AN ASSESSMENT OF EPIPODOPHYLLOTOXINS}

The epipodophyllotoxins were initially used by British paediatric oncologists in the late 1970s. Although teniposide has not been used much in Britain, it is used to treat substantial numbers of adults with cancer within mainland Europe-for example, in the treatment of lymphomas. Etoposide is used extensively within Britain in the treatment of cancer in adults and was initially introduced for the treatment of non-Hodgkin's lymphoma and acute leukaemia. It is of concern that our findings may apply to the treatment of adults with cancer and therefore there is a need for a similar study relating to adult patients. It would be prudent to use epipodophyllotoxins-particularly given with alkylating agents and radiotherapy-with caution in the treatment of childhood cancer, and if there exists an alternative regimen producing similar survival prospects but less risk of second neoplasms then this should be adopted. The results of this study should not be viewed too pessimistically since the few secondary leukaemias observed need to be considered against the thousands of patients who have experienced improved survival or have been cured as a result of using modern treatment methods.

It is not possible at present to give a detailed overall assessment of the clinical value of epipodophyllotoxins because there is insufficient information. This is because these agents are relatively new, and also they are usually used in combination with other cytotoxic agents with consequent difficulties in identifying the effects of individual drugs. For each cancer for which epipodophyllotoxins are proposed or used as a part of treatment the following questions need to be addressed: (1) How many extra patients diagnosed will survive with the use of epipodophyllotoxins within five (or 10) years compared with the best alternative regimen or protocol? (2) How many extra secondary malignant neoplasms will develop during the corresponding period? (3) Does comparison of (1) and (2) indicate there is a net advantage or disadvantage associated with the use of epipodophyllotoxins?

This simple formulation ignores other possible untoward effects of treatment that may also need to be taken into account. The most satisfactory source for such information is undoubtedly randomised clinical trials. As mentioned above, the United Kingdom Children's Cancer Study Group non-Hodgkin's lymphoma and $T$ cell leukaemia/lymphoma clinical trial treatment protocols which were used to treat patients diagnosed in the United Kingdom between mid- 1977 and mid- 1983 resulted in $7 \cdot 8 \%$ of patients developing a second malignant neoplasm by seven years from diagnosis. The protocols have subsequently been modified, and in particular adjuvant radiotherapy has been discontinued ${ }^{41} 45$ and teniposide replaced by etoposide. It is important that results from these trials are used to monitor changes in survival and the risk of secondary malignancy that are associated with the change of protocol.

With regard to conclusions to be drawn from the present study three aspects of the data should be emphasised. Firstly, the relation between exposure to epipodophyllotoxins and secondary leukaemia revealed evidence of a striking dose dependence in risk, and therefore whether to include epipodophyllotoxins as part of a treatment protocol might depend on whether it was proposed to give relatively high or low doses. Secondly, our data relate almost exclusively to teniposide, and the risk of secondary leukaemia after etoposide may be different. Thirdly, the majority of patients developing leukaemia after receiving an epipodophyllotoxin also received at least two alkylating agents and radiotherapy; consequently the risk of secondary leukaemia may be different after an epipodophyllotoxin given as part of a different treatment regimen.

\section{FURTHER STUDY: INTERNATIONAL COLLABORATION}

It is clear that there is a need to amalgamate the data from small case-control studies such as ours and that carried out by the Late Effects Study Group. In fact, our study was designed so that it would be possible easily to amalgamate the data from these two studies into one large data set that could be analysed afresh with the possibility of gaining new insights. In addition, given the rarity of second leukaemia within particular countries there is a clear need for wider international collaboration in combining the results from as many countries as could provide data. Anyone or any institution interested in collaborating in such an international collaborative case-control study of secondary leukaemia after childhood neoplasms is invited to write to $M M H$.

We offer particular thanks to Professor Nick Day and Dr Gerald Draper for support and advice throughout this study. We also thank members of the Childhood Cancer Research Group for contributing in various ways, particularly Diane Piper, Hazel Burton, Elizabeth Mowat, Penny Holt, David Winter, Clare Robertson, and Charles Stiller. We are grateful to the Long Term Follow-Up Study Working Party (Professor O B Eden, Professor D G Harnden, Dr J R Mann, Professor J S Malpas, Dr P H Morris Jones) for advice and support. Particular thanks are due to Professors A W Craft and M G Mott for helpful advice. We also thank the many consultants who gave access to medical records relating to patients. The long term follow up study is supported mainly by the Cancer Research Campaign, with some support from the Leukaemia Research Fund. The radiation dosimetry was funded by the National Cancer Institute through Dr J D Boice. The Childhood Cancer Research Group is supported by the Department of Health and the Scottish Home and Health Department. We are also grateful to the Office of Population Censuses and Surveys; the Information Services Division of the Common Services Agency of the Scottish Health Service; the regional cancer registries; the registrar general for 
Scotland; and the NHS central registers, Southport and Edinburgh.

\section{Addendum}

After preparation of this paper Pui and colleagues published an updated analysis of the risk of acute myeloid leukaemia after acute lymphocytic leukaemia among patients treated at the St Judes Children's Research Hospital. ${ }^{46}$ The series was initially reported in reference 16. The most striking aspect of this further analysis was the increased risk of secondary acute myeloid leukaemia among those patients who were given epipodophyllotoxins weekly or twice weekly compared with those treated every other week. However, Pui et al could not determine reliably whether the cumulative dose of epipodophyllotoxins was important in determining the risk of secondary acute myeloid leukaemia because of insufficient variation in cumulative dose. There are at least two important differences between our study and that of Pui et al. The cumulative doses of epipodophyllotoxins received by patients in our study were of order $100 \mathrm{~s}$ of $\mathrm{mg} / \mathrm{m}^{2}$ compared with $1000 \mathrm{~s}$ of $\mathrm{mg} / \mathrm{m}^{2}$ in the St Judes study. Furthermore, the intervals between administrations of epipodophyllotoxins were almost never within a week for patients included in our study; on average intervals were several weeks. Therefore, despite the comparatively smaller cumulative doses and longer intervals between exposures in our study there is clear evidence of a dose-response linking cumulative exposure to epipodophyllotoxins and the risk of secondary leukaemia. Careful consideration should be given to the use of epipodophyllotoxins in all clinical contexts.

1 Curtis RE, Hankey BF, Myers MH, Young JL Jr. Risk of leukemia associated with the first course of cancer treatment: an analysis of the surveillance, epidemiology, and end results program experience. $\mathcal{f}$ Natl Cancer Inst 1984;72:531-44.

2 Kaldor JM, Day NE, Band P, Choi NW, Clarke EA, Coleman MP, et al. Second malignancies following testicular cancer, ovarian cancer and Hodgkin's disease: an international collaborative study among cancer Hodgkin's disease: an international
registries. Int $f$ Cancer 1987;39:571-85.

3 Tucker MA, Coleman CN, Cox RS, Varghese A, Rosenberg SA. Risk of second cancers after treatment for Hodgkin's disease. $N$ Engl f Med 1988;318:76-8

4 Devereux S, Selassie TG, Vaughan Hudson G, Vaughan Hudson B, Linch DC. Leukaemia complicating treatment for Hodgkin's disease: the experience of the British national lymphoma investigation. BMF 1990;301:1077 80.

5 Boivin JF, Hutchison GB, Evans FB, Abou-Daoud KT, Junod B. Leukemia after radiotherapy for first primary cancers of various anatomic sites. $A m \mathcal{J}$ Epidemiol 1986;123:993-1003.

6 Travis LB, Curtis RE, Boice JD Jr, Hankey BF, Fraumeni JF Jr. Second cancers following non-Hodgkin's lymphoma. Cancer 1991;67:2002-9.

7 Tucker MA, Meadows AT, Boice JD Jr, Hoover RN, Fraumeni JF Jr. Cancer risk following treatment of childhood cancer. In: Boice JD, Fraumeni JF, eds. Radiation carcinogenesis: epidemiology and biological significance. New eds. Radiation carcinogenesis: epidem

8 Hawkins MM, Draper GJ, Kingston JE. Incidence of second primary tumours Hawkins MM, Draper GJ, Kingston JE. Incidence of second prima
among childhood cancer survivors. Br $\mathcal{f}$ Cancer 1987;56:339-47.

9 Kaldor JM, Day NE, Clarke EA, Van Leeuwen FE, Henri-Amar M, Fiorentino MV, et al. Leukemia following Hodgkin's disease. N Engl f Med 1990;322:7-13.

10 Kaldor JM, Day NE, Pettersson F, Clarke EA, Pedersen D, Mehnert W, et al. Leukemia following chemotherapy for ovarian cancer. $N$ Engl $\mathcal{Y} \mathrm{Med}$ 1990;322:1-6.

11 Haas JF, Kittelmann B, Mehnert WH, Staneczek W, Mohner M, Kaldor JM et al. Risk of leukaemia in ovarian tumour and breast cancer patients following treatment by cyclophosphamide. $\mathrm{Br} \mathcal{F}$ Cancer 1987;55:213-8.

12 Tucker MA, Meadows AT, Boice JD, Stovall M, Oberlin O, Stone BJ, et al. Leukemia after therapy with alkylating agents for childhood cancer. $\mathcal{F} \mathrm{Nall}$ Cancer Inst 1987;78:459-64.

13 Boice JD, Fraumeni JF, eds. Radiation carcinogenesis: epidemiology and biological significance. New York: Raven Press, 1984.

14 Ratain MJ, Kaminer LS, Bitran JD, Larson RA, Le Beau MM, Skosey C, et al. Acute non lymphocytic leukaemia following etoposide and cisplatin combination chemotherapy for advanced non-small-cell carcinoma of the lung. Blood 1987;70:1412-7.

15 Weh HJ, Kabisch H, Landbeck G, Hossfeld DK. Translocation (9;11) (p21 q23) in a child with acute monoblastic leukaemia following 21/2 years after
successful chemotherapy for neuroblastoma. F Clin Oncol 1986;4:1518-20.
6 Pui CH, Behm FG, Raimondi SC, Dodge RK, George SL, Rivera GK, et al. Secondary acute myeloid leukemia in children treated for acute lymphoid leukemia. N Engl f Med 1989;321:136-42.

17 Kreissman SG, Gelber RD, Sallam SE, Leavitt P, Cohen HJ. Secondary acute myeloid leukaemia (AML) in children treated for acute lymphoblastic leukaemia (ALL) [abstract]. Proceedings of the American Society of Clinical Oncology 1990;9:219.

18 Pui CH, Hancock ML, Raimondi SC, Head DR, Thompson E, Wilimas J, et al. Myeloid neoplasia in children treated for solid tumours. Lancet 1990;336:417-21.

19 Pui CH. Therapy-related myeloid leukaemia. Lancet 1990;336:1130-1.

20 Pedersen-Bjergaard J, Daugaard G, Hansen SW, Philip P, Larsen SO, Rorth $\mathrm{M}$, et al. Increased risk of myelodysplasia and leukaemia after etoposide, cisplatin and bleomycin for germ-cell tumours. Lancet 1991;338:359-63.

21 Whitlock JA, Greer JP, Lukens JN. Epipodophyllotoxin-related leukemia. Identification of a new subset of secondary leukemia. Cancer 1991;68:600-4.

22 Breslow NE, Day NE. Statistical methods in cancer research: the design and analysis of cohort studies. Lyons: International Agency for Research on Cancer, 1987. (IARC Scientific Publication 82.)

23 Peto R, Pike MC, Armitage P, Breslow NE, Cox DR, Howard SV, et al. Design and analysis of randomized clinical trials requiring prolonged observation of each patient: analysis and examples. Br $\mathcal{J}$ Cancer 1977;35: 1-39.

24 Breslow NE, Day NE. Statistical methods in cancer research: the analysis of casecontrol studies. Lyons: International Agency for Research on Cancer, 1980. (IARC Scientific Publication 32.)

25 EGRET reference manual-first draft. Seattle: Statistics and Epidemiology Research Corporation, 1990.

26 Christy M. Mathematical phantoms representing children of various ages for use in estimates of internal dose. Washington, DC: US Nuclear Regulatory Commission, 1980. (ORNL Report NUREG/CRE; 1159.)

27 Stovall $M$, Smith SA, Rosenstein $M$. Tissue doses from radiotherapy of cancer of the uterine cervix. Med Phys 1989;16:726-33.

28 Secker-Walker LM, Stewart EL, Todd A. Acute lymphoblastic leukemia with $t(4 ; 11)$ follows neuroblastoma: a late effect of treatment? Med Pediatr Oncol 1985;13:48-50.

29 Derbyshire PJ, Mott MG. Secondary acute myeloid leukaemia in a boy with Tcell lymphoma: successful treatment by bone marrow transplantation. Clin Lab Haematol 1986;8:71-5.

30 DeVore R, Whitlock J, Hainsworth JD, Johnson DH. Therapy-related acute non-lymphocytic leukemia with monocytic features and rearrangement of chromosome 11q. Ann Intern Med 1989;110:740-2.

31 Prieto F, Palau F, Badia L, Beneyto M, Perez-Sirvent ML, Orts A, et al. $11 \mathrm{q} 23$ abnormalities in children with acute nonlymphocytic leukemia (M4-MS): association with previous chemotherapy. Cancer Genet Cytogenet 1990;45: $1-11$.

32 Le Beau MM, Albain KS, Larson RA, Vardiman JW, Davis EM, Blough RR, et al. Clinical and cytogenetic correlations in 63 patients with therapy-related myelodysplastic syndromes and acute nonlymphocytic leukaemia: further evidence for characteristic abnormalities of chromosomes no 5 and $7 . \mathcal{F} \mathrm{Clin}$ Oncol 1986;4:325-45.

33 Kantariian HM, Keating MJ, Walters RS, Smith TL, Cork A, McCredie KB, et al. Therapy-related leukaemia and myelodysplastic syndrome: clinical, et al. Therapy-related leukaemia and myelodysplastic syndrome:
cytogenetic, and prognostic features. $\mathcal{F}$ Clin Oncol 1986;4:1748-57.

34 Whang-Peng J, Young RC, Lee EC, Longo DL, Schechter GP, DeVita VT, $e t$ al.Cytogenetic studies in patients with secondary leukaemia/dysmyelopoietic syndrome after different treatment modalities. Blood 1988;71:403-14

35 Third MIC Cooperative Study Group (1987). Morphologic, immunologic and cytogenetic (MIC) working classification of the primary myelodysplastic syndromes and therapy-related myelodysplasias and leukemias. Cancer Genet Cytogenet 1988;32:1-10

36 Boice JD, Greene MH, Killen JY, Ellenberg SS, Keehn RJ, McFadden E, $e t$ al. Leukemia and preleukemia after adjuvant treatment of gastrointestinal cancer with semustine (methyl-CCNU). N Engl f Med 1983;309:1079-84.

37 Greene MH, Harris EL, Gershenson DM, Malkasian GD, Melton LJ, Dembo AJ, et al. Melphalan may be a more potent leukemogen than cyclophosphamide. Ann Intern Med 1986;105:360-7.

38 Cuzick J, Erskine S, Edelman D, Galton DAG. A comparison of the incidence of the myelodysplastic syndrome and acute myeloid leukaemia following of the myelodysplastic syndrome and acute myeloid leukaemia following
melphalan and cyclophosphamide treatment for myelomatosis. A report to melphalan and cyclophosphamide treatment for myelomatosis. A report to
the Medical Research Council's working party on leukaemia in adults. $\mathrm{Br} f$ the Medical Research $1987 ; 55: 523-9$.

39 de Vathaire F, François P, Hill C, Schweisguth O, Rodary C, Sarrazin D, et al. Role of radiotherapy and chemotherapy in the risk of second malignant Role of radiotherapy and chemotherapy in the risk of second
neoplasms after cancer in childhood. Brf Cancer 1989;59:792-6.

40 Ingram L, Mott MG, Mann JR, Raafat F, Darbyshire PJ, Morris Jones PH. Second malignancies in children treated for non-Hodgkin's lymphoma and T-cell leukaemia with the UKCCSG regimens. Br $\mathcal{A}$ Cancer 1987;55:463-6.

41 Mott MG, Eden OB, Palmer MK. Adjuvant low dose radiation in childhood non-Hodgkin's lymphoma. Br f Cancer 1984;50:463-9.

42 Long BH, Musial ST, Brattain MG. Single and double strand DNA breakage and repair in human lung adenocarcinoma cells exposed to etoposide and teniposide. Cancer Res 1985;45:3106-12.

43 Ross W, Rowe T, Glisson B, Yalowich J, Liu L. Role of topoisomerase II in mediating epipodophyllotoxin-induced DNA cleavage. Cancer Res 1984;44: $5857-60$

44 Boice JD Jr, Blettner M, Kleinerman RA, Stovall M, Moloney WC, Engholm $\mathrm{G}$, et al. Radiation dose and leukemia risk in patients treated for cancer of the G, et al. Radiation dose and leukemia risk in pate
cervix. F Natl Cancer Inst 1987;79:1295-1311.

45 Mott MG, Chessells JM, Willoughby MLN, Mann JR, Morris Jones PH, Malpas JS, et al. Adjuvant low dose radiation in childhood T-cell leukaemia/ lymphoma. Brf Cancer 1984;50:457-62.

46 Pui CH, Ribeiro RC, Hancock ML, Rivera GK, Evans WE, Raimondi SC, et al. Acute myeloid leukemia in children treated with epipodophyllotoxins for acute lymphoblastic leukemia. $N$ Englf M Med 1991;325:1682-7.

(Accepted 23 fanuary 1992) 